\title{
First parasitological study of the African clawed frog (Xenopus laevis, Amphibia) in Chile
}

\author{
Primeiro estudo parasitológico em rã com garras Africano (Xenopus laevis, Anfibia) no Chile

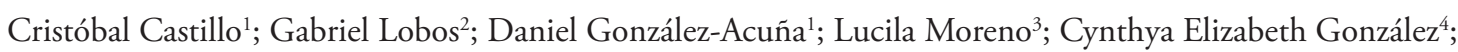 \\ Carlos Landaeta-Aqueveque ${ }^{1 *}$
}

${ }^{1}$ Facultad de Ciencias Veterinarias, Universidad de Concepción, Chillán, Chile

${ }^{2}$ Centro de Gestión Ambiental y Biodiversidad, Facultad de Ciencias Veterinarias y Pecuarias, Universidad de Chile, Santiago, Chile

${ }^{3}$ Facultad de Ciencias Naturales y Oceanográficas, Universidad de Concepción, Concepción, Chile

${ }^{4}$ Centro de Ecología Aplicada del Litoral, Consejo Nacional de Investigaciones Científicas y Técnicas, Corrientes, Argentina

Received November 27, 2016

Accepted April 27, 2017

\begin{abstract}
Introduced species can arrive into new territories with parasites; however, these species are expected to face lower parasite richness than in their original regions. Both introduced hosts and parasites can affect native fauna. Since their release into the wild in Chile following laboratory use, Xenopus laevis Daudin, 1802 has widely spread throughout central Chile. The only pathogen described on the host is the fungus Batrachochytrium dendrobatidis Longcore, Pessier, Nichols, 1999; thus, this is the first parasitological study of this species in Chile. In 10 localities in central Chile, 179 specimens of $X$. laevis were captured and examined for parasites in the gastrointestinal tube, cavities, lungs, liver, and skin. Only nine specimens of the genus Contracaecum Railliet, Henry, 1912 were found in six specimens of X. laevis from a private dam in La Patagua. It is likely that these parasites originated from species of native birds. This is the first record of Contracaecum sp. in Chilean amphibians.
\end{abstract}

Keywords: Contracaecum, nematode, invasive, anisakid.

\section{Resumo}

Espécies exóticas podem se introduzir em um novo território com seus parasitas, porém nesses casos, a riqueza parasitária seria menor. Contudo, hospedeiros exóticos e seus parasitas associados podem afetar a fauna nativa. Depois de ser dispensado do uso em laboratórios e solto em ambientes naturais, Xenopus laevis Daudin, 1802 tem se espalhado massivamente no Chile central. O único patógeno descrito para este anuro é o fungo Batrachochytrium dendrobatidis Longcore, Pessier, Nichols, 1999. O presente estudo constitui a primeira pesquisa parasitológica realizada nesta espécie de rã introduzida no Chile. Em 10 localidades do Chile central, foram capturados 179 espécimes de X. laevis que foram examinadas em busca de parasitos dentro tubo digestivo, cavidades corporais, pulmóes, fígado e pele. Nove espécimes do gênero Contracaecum Railliet, Henry, 1912 foram encontrados em seis espécimes de X. laevis de uma barragem em La Patagua. É provável que a origem destes parasitas sejam espécies de aves nativas. Este é o primeiro relato de Contracaecum sp. em anuros do Chile.

Palavras-chave: Contracaecum, nematoide, invasivo, anisaquídeos.

\section{Introduction}

Invasive species constitute some of the most important causes of biodiversity loss (WILCOVE et al., 1998; WILCOVE \& MASTER, 2005). In this context, introduced (non-native) free-living species usually arrive to a new territory with lower parasite richness when compared to what is observed in their

${ }^{*}$ Corresponding author: Carlos Landaeta-Aqueveque. Facultad de Ciencias Veterinarias, Universidad de Concepción, Vicente Méndez, 595, Chillán, Chile. e-mail: clandaeta@udec.cl original locality (TORCHIN et al., 2003). This can be due to the fact that some parasites are not represented in the population taken from the native geographic range; other parasites are taken with the hosts, but they do not arrive to the new territory, and those parasites that do arrive to the new territory may not survive and reproduce therein (MACLEOD et al., 2010). This suggests that there is an advantage for those invasive species that release from their parasites. However, some parasites can be transported to a 
new territory and naturalize in such a way that the introduced host may act as source of introduced parasites for native free-living species (SMITH \& CARPENTER, 2006; LYMBERY et al., 2014), or they can also catch native parasites (KELLY et al., 2009a; JOHNSON \& THIELTGES, 2010; MASTITSKY \& VERES, 2010), affecting the dynamic of both native hosts and parasites (KELLY et al., 2009b; LYMBERY et al., 2014). Thus, the study of parasites of invasive species fosters an understanding of the underlying processes that positively or negatively affect these species.

The clawed frog, Xenopus laevis Daudin, 1802, is native to Africa and has been introduced to Europe, Asia, North America, and South America, for both scientific use and pet trade (MEASEY et al., 2012). In Chile, this frog was introduced into the wild in 1973, when an unknown number of individuals was dumped into the Caren Lagoon, which is close to Santiago's international airport (JAKSIC, 1998). The first naturalized population (stage III, after COLAUTTI \& MACISAAC, 2004) was recorded the beginning of the 1980s (VELOSO \& NAVARRO, 1988). Xenopus laevis spread from this lagoon on its own to other lagoons, ponds, dams, and watercourses around Santiago, although it has also translocated from Caren Lagoon to other bodies of water (LOBOS \& JAKSIC, 2005). The spread rate of this frog in Chile was estimated to be between 3.1 and $5.4 \mathrm{~km} /$ year, reaching an invaded area of about $21,200 \mathrm{~km}^{2}$ in the last decade; this area accounts for four of the fifteen administrative regions (LOBOS \& JAKSIC, 2005) and the African clawed frog is expected to invade further north and south in Chile (LOBOS et al., 2013).

At present, the only important pathogen reported in $X$. laevis in Chile is Batrachochytrium dendrobatidis Longcore, Pessier, Nichols, 1999, which is the etiological agent underlying chytridiomycosis - a disease that has resulted in the population decline and extinction of several anuran species worldwide (SOLÍS et al., 2010) and is considered a notifiable disease by OIE (2010). Studies on the helminth parasites of $X$. laevis have not been performed in Chile; however, many helminth species have been described in feral populations in North America (KUPERMAN et al., 2004) and in wild populations in Africa (PRITCHARD, 1964; MACNAE et al., 1973; WADE, 1982; TINSLEY, 1996). Thus, in order to describe the antecedents involved in the process $X$. laevis invasion in Chile, in this study, we aimed to analyze the gastrointestinal and external parasite community of this species of frog in this territory.

\section{Materials and Methods}

From 1997-2014, 179 adult $X$. laevis were caught from 10 localities in central Chile: El Tabo (Córdova stream; coordinates: $33^{\circ} 26^{\prime} 0.05^{\prime}$ 'S, 7138'44.61”W; $\mathrm{n}=9$ individuals), El Yali National Reserve (Los Molles dam: 3348'3.60”S, 7141'49.21”W; n = 2), Tejas Verdes (Maipo river: 3337’42.25”S, 71³6’30.80”W; $n=3$ ),

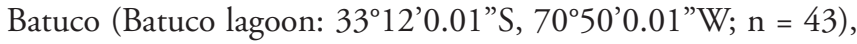

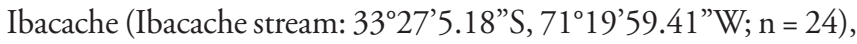
La Pintana (Universidad de Chile: 3334’23.88”S, 70³7’57.64”W; $\mathrm{n}=5$ ), Las Chilcas (Chilcas stream: 3252'17.24”S, 7050'43.19”W;

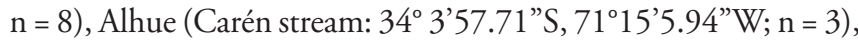
Palmilla (Tinguiririca river: $34^{\circ} 35^{\prime} 49.14^{\prime \prime}$ S, $71^{\circ} 21^{\prime} 20.29^{\prime \prime} \mathrm{W} ; \mathrm{n}=3$ ), and La Patagua (private dam: 3442'59.26”S, 71'23’5.94”W; $\mathrm{n}=79$ ).

Frogs of La Patagua were actively caught from a dam with use of an ad hoc mesh; in this dam, the frogs were apparent in high densities. In the other localities, the frogs were captured using simple funnel traps (buckets with tight-fitting lids, modified by the lateral insertion of open cones) and baited with liver. After they were euthanized in benzocaine immersion (see CHARBONNEAU et al. 2010), the frogs were preserved in $70 \%$ ethanol and examined in the laboratory under stereomicroscope. They were assessed for helminths through the gastrointestinal tube, cavities, lungs, liver, and skin. Nematodes were preserved in $70 \%$ ethanol and cleared with lactophenol for light microscope examination. For the prevalence of infection, refer to Margolis et al. (1982). The Comité de Ética of the Facultad de Ciencias Veterinarias - Universidad de Concepción approved and certified the study (certificate number CBE 23-12). Specimens of nematode parasites were deposited into the Helminthological Collection of Centro de Ecología Aplicada del Litoral (CECOAL 16110301; there were a total of 7 specimens).

\section{Results and Discussion}

Only nine specimens of nematodes were found in six frogs (prevalence: $3.4 \%$ ) from La Patagua. They were found encapsulated in the intestinal serosa and were subsequently identified as larvae of the genus Contracaecum Railliet and Henry, 1912. Genus identification was based on morphological attributes (HARTWICH, 2009): the presence of a posterior ventricular appendix, an anterior intestinal caecum, the excretory pore at the base of the ventral labia, and a rounded tail (Figure 1). Measurements $(\mu \mathrm{m}$; mean \pm standard deviation) of eight larvae (unless otherwise stated) were: total length $2,100 \pm 380$, width: $116.66 \pm 12.74$, cecum length: $173.75 \pm 69.7$, esophagus length: $269 \pm 54$, distance excretory pore - anterior end: $15 \pm 42$ (two individuals), distance nerve ring - anterior end: 47 (one individual), tail length: $76.25 \pm 11.08$ (four individuals). Given the small number of specimens and the fact that they were larvae, it was not possible to identify the species. No external parasites were found.

Given the various processes that make the arrival and establishment of parasites to new territories difficult (MACLEOD et al., 2010), the reduced parasite richness of an invasive host species in the colonized territory, when compared to its original geographic range, is expected. Thus, our results were in line with our expectations, particularly as a greater richness of gastrointestinal and cavity helminths have been recorded in $X$. laevis in South Africa. For instance, some of the helminth species reported in African clawed frogs include Cephalochalamys namaquensis Cohn, 1906 (cestode); Protopolystoma xenopodis Price, 1943; Gyrdicotylus gallieni Vercammen-Grandjean, 1960 (monogenean); Oligolecithus jonkershoekensis Pritchard, 1964; and Progonimodiscus doyeri Ortlepp, 1926 (digenean) (PRITCHARD, 1964; THEUNISSEN et al., 2014). For a further review, see Tinsley (1996). In addition, in this study, the prevalence of Contracaecum sp. was low, and the parasites were present in only one geographical location, La Patagua. This lack of helminths in most clawed frogs means that there is a lack of enemies (parasitic helminths), enhancing the survival, 


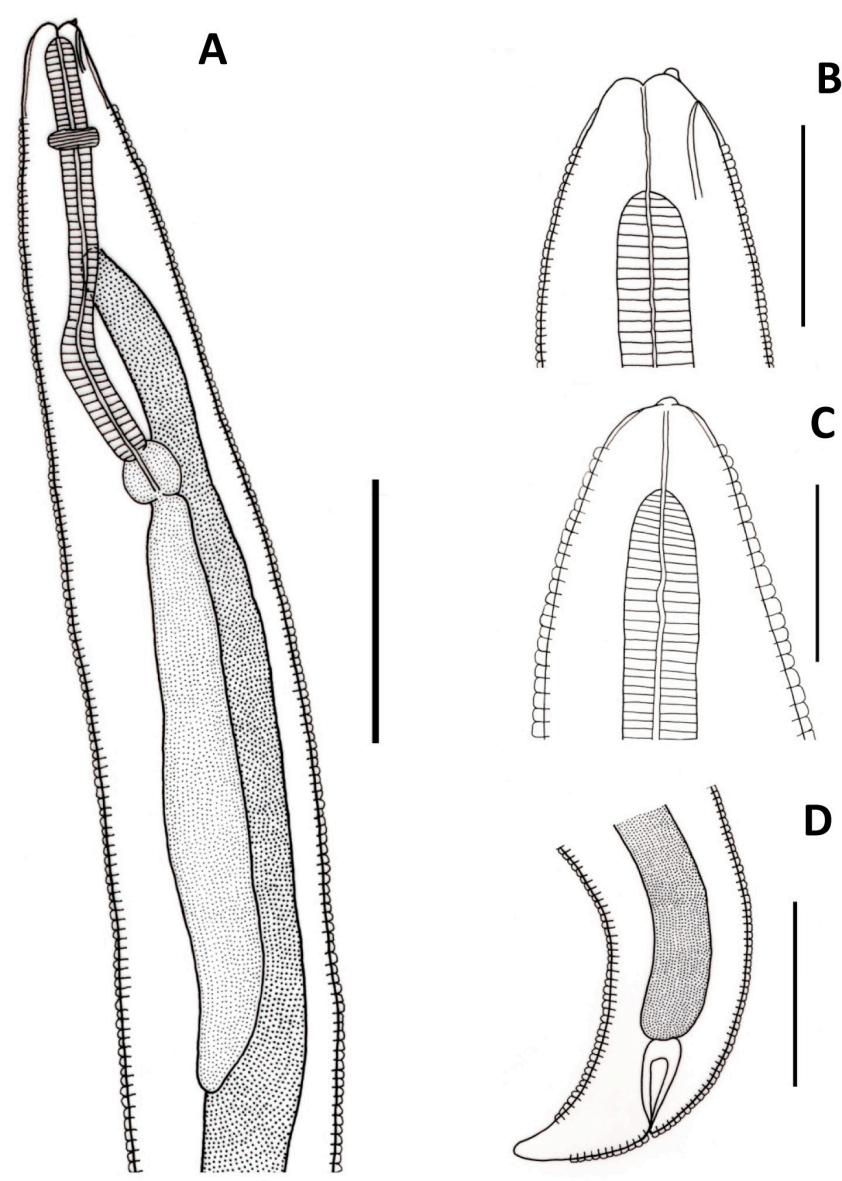

Figure 1. Contracaecum sp. larvae from the intestinal serosa of Xenopus laevis from La Patagua, Chile: (A) Anterior end; (B) Lateral view of the cephalic portion; (C) Dorsal view of the cephalic portion; (D) Lateral view of the posterior end. Scale bars: A, D: $100 \mu \mathrm{m}$; B, C: $50 \mu \mathrm{m}$.

which may favor the process of invasion by X. laevis. More studies are necessary to confirm this hypothesis. The parasitic richness found in our study is also lower than what was previously found in other territories invaded by this frog, including California, where at least seven species of helminths have been reported in the same anatomical parts of the frogs investigated in this study. These helminths included the following: C. namaquensis, G. gallieni, P. xenopodis, Clinostomum sp., Contracaecum sp., Eustrongylides sp., and Acanthocephalus sp. (LAFFERTY \& PAGE, 1997; KUPERMAN et al., 2004). Further studies are necessary to test the possible reasons underlying this difference.

In addition to $X$. laevis from California (with prevalences (P) similar to our study, varying from 0 to $4 \%$ ), the genus Contracaecum was reported in Argentina in another introduced amphibian species: Lithobates catesbeianus Shaw, 1802 ( $\mathrm{P}=43.7 \%)$ (GONZÁLEZ et al., 2014); this genus was also reported in the native Bufo marinus Linnaeus, 1758 (ESPINOZA-JIMÉNEZ et al., 2007) from Mexico ( $P=4.2 \%)$; in both cases showing higher prevalences than in our study. In Chile, this genus was found in other groups of vertebrates, including birds ( $\mathrm{P}>17.4 \%)$ and fish ( $\mathrm{P}=13.3 \%)$ (TORRES et al., 1982, 1983, 1991, 2005; TORRES \& CUBILLOS, 1987; GONZÁLEZ-ACUÑA et al., 2008).
However, as far as we know, this is the first record of an anisakid species in amphibians from Chile. Other taxa of nematodes found in amphibians native to Chile include Rhabdias sp. ( $\mathrm{P}=36 \%)$ (Rhabditida, Rhabdiasidae); Parapharyngodon sceleratus Travassos, 1923 (P = 20-100\%); Spauligodon maytacapaci Vicente, Ibánez, 1968 (P = 40-92\%) (Oxyurida, Pharyngodonidae); Aplectana artigasi Puga, Torres, 1997 ( $\mathrm{P}=23-100 \%)$; Aplectana chilensis Lent, Freitas, 1948 (P = 64\%); Cosmocerca chilensis Lent, Freitas, 1948 (unreported prevalence) (Ascaridida, Cosmocercidae); Skrjabinelazia sp. $(\mathrm{P}=3.3 \%)$ (Ascaridida, Seuratidae); Physaloptera cf. lutzi Cristófaro, Guimaraes, Rodríguez, 1976 (P = 3-19\%); Physaloptera sp. $(\mathrm{P}=15 \%)$ (Spirurida, Physalopteridae); Oswaldocruzia neghmei Puga, 1981 ( $\mathrm{P}=7-100 \%)$; and Oswaldocruzia sp. ( $\mathrm{P}=7 \%)$ (Sotrongylida, Molineidae) (GARÍN \& GONZÁLEZ-ACUÑA, 2008).

Given that Contracaecum display an indirect cycle in which the frogs are intermediate hosts, and where laboratory-bred clawed frogs serve as the source of the invasive population (LOBOS et al., 2014), the source of infection for those frogs with Contracaecum sp. was more likely the native fauna of Chile, particularly native birds (definitive hosts) than the native range of $X$. laevis (i. e., African infection that persisted through the laboratory breeding in Chile).

Birds are frequently mentioned as hosts of Contracaecum sp. One cormorant species, Phalacrocorax brasilianus (syn olivaceus) Gmelin, 1789 (TORRES, 1983; TORRES et al., 1991, 2005), and three gull species - Larus dominicanus Lichtenstein, 1823, Larus (syn. Chroicocephalus) maculipennis Lichtenstein, 1823, and Larus serranus Tschudi, 1844 (TORRES et al., 1983) were found to be parasitized with Contracaecum in Chile, with Contracaecum rudophii Hartwich, 1964 as the one parasite species found in all cases. In addition, birds, including L. dominicanus, are also the main predators of $X$. laevis; there are two other bird species reported as predators of $X$. laevis: Athene (syn. Speotyto) cunicularia Molina, 1782 and Nycticorax nycticorax Linnaeus, 1758 (LOBOS \& JAKSIC, 2005). While this suggests that $X$. laevis facilitates the infection of this gull by serving as an intermediate host for Contracaecum sp. and as prey for L. dominicanus, the low prevalence and abundance of this parasite in $X$. laevis may mean that this frog is of low importance in the infection of gulls by Contracaecum nematodes.

\section{Acknowledgements}

This study was funded by the Fondo Nacional de Desarrollo Científico y Tecnológico de Chile (grant numbers: 1130948 and 1170972).

\section{References}

Charbonneau R, Niel L, Olfert E, von Keyserlingk M, Griffin C. CCAC guidelines on: euthanasia of animals used in science. Ottawa: Canadian Council on Animal Care; 2010.

Colautti RI, MacIsaac HJ. A neutral terminology to define 'invasive' species. Divers Distrib 2004; 10(2): 135-141. http://dx.doi.org/10.1111/j.13669516.2004.00061.x. 
Espinoza-Jiménez A, García-Prieto L, Osorio-Sarabia D, León-Règagnon V. Checklist of helminth parasites of the cane toad Bufo marinus (Anura: Bufonidae) from Mexico. J Parasitol 2007; 93(4): 937-944. PMid:17918380. http://dx.doi.org/10.1645/GE-1047R.1.

Garín C, González-Acuña D. Parásitos de anfibios y reptiles. In: Vidal MA, Labra A. Herpetologia de Chile. Santiago: Science Verlag; 2008. p. 303-332.

González CE, Quiroga LB, Sanabria EA. First survey of nematode parasites in introduced American bullfrogs (Lithobates catesbeianus) in Argentina. Comp Parasitol 2014; 81(2): 284-287. http://dx.doi.org/10.1654/4700.1.

González-Acuña D, Kinsella JM, Lara J, Valenzuela-Dellarossa G. Parásitos gastrointestinales en pingüino de Humboldt (Spheniscus humboldti) y pingüino de Magallanes (Spheniscus magellanicus) en las costas del centro y centro sur de Chile. Parasitol Latinoam 2008; 63(1-2-3-4): 58-63. http:// dx.doi.org/10.4067/S0717-77122008000100010.

Hartwich G. Ascaridida. In: Anderson RC, Chabaud AG, Wilmott S. Keys to the nematode parasites of vertebrates. Wallingford: CAB International; 2009. p. 309-323.

Jaksic FM. Vertebrate invaders and their ecological impacts in Chile. Biodivers Conserv 1998; 7(11): 1427-1445. http://dx.doi. org/10.1023/A:1008825802448.

Johnson PTJ, Thieltges DW. Diversity, decoys and the dilution effect: how ecological communities affect disease risk. J Exp Biol 2010; 213(6): 961-970. PMid:20190121. http://dx.doi.org/10.1242/jeb.037721.

Kelly DW, Paterson RA, Townsend CR, Poulin R, Tompkins DM. Parasite spillback: a neglected concept in invasion ecology? Ecology 2009a; 90(8): 2047-2056. PMid:19739367. http://dx.doi.org/10.1890/08-1085.1.

Kelly DW, Paterson RA, Townsend CR, Poulin R, Tompkins DM. Has the introduction of brown trout altered disease patterns in native New Zealand fish? Freshw Biol 2009b; 54(9): 1805-1818. http://dx.doi. org/10.1111/j.1365-2427.2009.02228.x.

Kuperman BI, Matey VE, Fisher RN, Ervin EL, Warburton ML, Bakhireva $\mathrm{L}$, et al. Parasites of the African clawed frog, Xenopus laevis, in Southern California, U.S.A. Comp Parasitol 2004; 71(2): 229-232. http://dx.doi. org/10.1654/4112.

Lafferty KD, Page CJ. Predation on the Endangered Tidewater Goby, Eucyclogobius newberryi, by the Introduced African Clawed Frog, Xenopus laevis, with Notes on the Frog's Parasites. Copeia 1997; 1997(3): 589-592. http://dx.doi.org/10.2307/1447564.

Lobos G, Cattan P, Estades C, Jaksic FM. Invasive African clawed frog Xenopus laevis in southern South America: key factors and predictions. Stud Neotrop Fauna Environ 2013; 48(1): 1-12. http://dx.doi.org/10.1 080/01650521.2012.746050.

Lobos G, Jaksic FM. The ongoing invasion of African clawed frogs (Xenopu laevis) in Chile: causes of concern. Biol Conserv 2005; 14(2): 429-439.

Lobos G, Mendez MA, Cattan P, Jaksic F. Low genetic diversity of the successful invasive African clawed frog Xenopus laevis (Pipidae) in Chile. Stud Neotrop Fauna Environ 2014; 49(1): 50-60. http://dx.doi.org/10.1 080/01650521.2014.912865.

Lymbery AJ, Morine M, Kanani HG, Beatty SJ, Morgan DL. Co-invaders: the effects of alien parasites on native hosts. Int J Parasitol Parasites Wildl 2014; 3(2): 171-177. PMid:25180161. http://dx.doi.org/10.1016/j. ijppaw.2014.04.002.

MacLeod CJ, Paterson AM, Tompkins DM, Duncan RP. Parasites lost: do invaders miss the boat or drown on arrival? Ecol Lett 2010; 13(4): 516-527. PMid:20455925. http://dx.doi.org/10.1111/j.1461-0248.2010.01446.x.
Macnae W, Rock L, Makowski M. Platyhelminths from the South African clawed toad, or platanna (Xenopus laevis). J Helminthol 1973; 47(1): 199235. http://dx.doi.org/10.1017/S0022149X00023890.

Margolis L, Esch GW, Holmes JC, Kuris AM, Schad GA. The use of ecological terms in parasitology: report of an Ad Hoc Committee of the American Society of Parasitologists. J Parasitol 1982; 68(1): 131-133. http://dx.doi.org/10.2307/3281335.

Mastitsky SE, Veres JF. Field evidence for a parasite spillback caused by exotic mollusc Dreissena polymorpha in an invaded lake. Parasitol Res 2010; 106(3): 667-675. PMid:20107837. http://dx.doi.org/10.1007/ s00436-010-1730-4.

Measey GJ, Rödder D, Green SL, Kobayashi R, Lillo F, Lobos G, et al. Ongoing invasions of the African clawed frog, Xenopus laevis: a global review. Biol Inv 2012; 14(11): 2255-2270. http://dx.doi.org/10.1007/ s10530-012-0227-8.

Pritchard MH. Notes on four helminths from the clawed toad, Xenopus laevis (Daudin), in South Africa. Proc Helminthol Soc Wash 1964; 31(1): 121-128.

Smith KF, Carpenter SM. Potential spread of introduced black rat (Rattus rattus) parasites to endemic deer mice (Peromyscus maniculatus) on the California Channel Islands. Div Distribut 2006; 12(6): 742-748. http:// dx.doi.org/10.1111/j.1472-4642.2006.00279.x.

Solís R, Lobos G, Walker SF, Fisher M, Bosch J. Presence of Batrachochytrium dendrobatidis in feral populations of Xenopus laevis in Chile. Biol Inv 2010; 12(6): 1641-1646. http://dx.doi.org/10.1007/s10530-009-9577-2.

Theunissen M, Tiedt L, Du Preez LH. The morphology and attachment of Protopolystoma xenopodis (Monogenea: Polystomatidae) infecting the African clawed frog Xenopus laevis. Parasite 2014; 21: 20. PMid:24823278. http://dx.doi.org/10.1051/parasite/2014020.

Tinsley RC. Parasites of Xenopus. In: Tinsley RC, Koble HR. The biology of Xenopus. Oxford: Clarendon Press; 1996. p. 233-261.

Torchin ME, Lafferty KD, Dobson AP, McKenzie VJ, Kuris AM. Introduced species and their missing parasites. Nature 2003; 421(6923): 628-630. PMid:12571595. http://dx.doi.org/10.1038/nature01346.

Torres P, Cubillos V. Infección por larvas de Contracaecum (Nematoda, Anisakidae) en salmónidos introducidos en Chile. J Vet Med Ser B 1987 34(1-10): 177-182. http://dx.doi.org/10.1111/j.1439-0450.1987.tb00385.x.

Torres P, Figueroa L, Saldivia A, Barrientos J. Gastrointestinal helminths of fish-eating birds from the Valdivia River, Chile. J Parasitol 1982; 68(6): 1157. http://dx.doi.org/10.2307/3281111.

Torres P, Ortega J, Schlatter R. Nematode parasites of the digestive tract in Neotropic cormorant chicks (Phalacrocorax brasilianus) from the River Cruces Ramsar site in southern Chile. Parasitol Res 2005; 97(2): 103 107. PMid:15986255. http://dx.doi.org/10.1007/s00436-005-1372-0.

Torres P, Ruíz E, Gesche W, Montefusco A. Gastrointestinal helminths of fish-eating birds from Chiloe Island, Chile. J Wildl Dis 1991; 27(1): 178-179. PMid:2023322. http://dx.doi.org/10.7589/0090-3558-27.1.178

Torres P, Sierpe V, Schlatter R. Occurrence of Contracaecum rudolphii in new hosts in Chile. Z Parasitenkd 1983; 69(3): 397-399. http://dx.doi. org/10.1007/BF00927883.

Torres P. Contracaecum sp. larvae in Galaxia platei from Calafquén Lake, Chile. Bol Chil Parasitol 1983; 38(1-2): 31-32. PMid:6661276.

Veloso A, Navarro J. Lista sistemática y distribución geográfica de anfibios y reptiles de Chile. Boll Mus Reg Sci Nat 1988; 6(2): 481-540. 
Wade SE. Capillaria xenopodis sp. n. (Nematoda: Trichuroidea) from the epidermis of the South African clawed frog (Xenopus laevis Daudin). Proc Helminthol Soc Wash 1982; 49(1): 86-92.

Wilcove DS, Master LL. How many endangered species are there in the United States? Front Ecol Environ 2005; 3(8): 414-420. http://dx.doi. org/10.1890/1540-9295(2005)003[0414:HMESAT]2.0.CO;2.
Wilcove DS, Rothstein D, Dubow J, Phillips A, Losos E. Quantifying Threats to Imperiled Species in the United States. BioSci 1998; 48(8): 607-615. http://dx.doi.org/10.2307/1313420.

World Organisation for Animal Health - OIE. OIE Listed diseases [online]. 2010 [cited 2017 Mar 25]. Available from: http://web.oie.int/ eng/maladies/en_classification2010.htm 